\title{
1 Title: Improved management facilitates return of an iconic fish species
}

2 Authors: Brian R. MacKenzie ${ }^{1 *}$, Kim Aarestrup ${ }^{2}$, Mads Christoffersen ${ }^{3}$, Mark R. Payne ${ }^{1}$, Claus

3 Sørensen $^{4}$, Henrik S. Lund ${ }^{5}$, Michele Casini ${ }^{6}$

\section{Affiliations:}

5

$6 \quad{ }^{1}$ National Institute for Aquatic Resources (DTU Aqua), Section for Oceans and Arctic, Technical

7 University of Denmark, Kemitorvet, Building 150, DK 2800 Kongens Lyngby, Denmark;

$8 \quad{ }^{2}$ National Institute for Aquatic Resources (DTU Aqua), Section for Freshwater Fisheries

$9 \quad$ Ecology, Technical University of Denmark, Silkeborg, Denmark;

$10{ }^{3}$ National Institute for Aquatic Resources (DTU Aqua), Section for Ecosystem Based Marine

11 Management, Technical University of Denmark, Kemitorvet, Building 150, DK 2800 Kongens

12 Lyngby, Denmark;

$13 \quad{ }^{4}$ Marinexperten, H.C.Ørstedsvej 9, DK 9900 Frederikshavn, Denmark

$14{ }^{5}$ Danish Fishermen Producer Organisation, Nordensvej 3, Taulov, DK 7000 Fredericia, Denmark

$15{ }^{6}$ Swedish University of Agricultural Sciences, Department of Aquatic Resources, Institute of

16 Marine Research, Turistgatan 5, Lysekil 45330, Sweden

17 *Correspondence to: brm@aqua.dtu.dk. 
Abstract:

21 Declines and losses of biota which persist for long periods often lead to a shifting baseline of

22 where populations and species should live and neglect or abandonment of recovery actions

23 aimed at ecological restoration. Such declines are frequently accompanied by contractions in

24 distribution, negative ecological impacts and diminishing economic benefits. Here we show

25 using citizen science information and data that after 50-60 years of near total absence from

26 waters near Denmark, Norway and Sweden, the iconic top predator and highly migratory species

27 bluefin tuna, Thunnus thynnus, returned by the hundreds if not thousands during August-October

28 2016. This remarkable return has been facilitated by improved fishery management for bluefin

29 tuna and its prey. Its reappearance, despite a recent history of mismanagement and illegal

30 fishing which led to population decline, offers hope that other marine ecological recoveries are

31 possible under improved management of fisheries and ecosystems.

Short title: Return of an iconic fish species

One Sentence Summary: Improved management helps bring back an ocean icon to northern

Europe.

\section{Significance Statement:}

38 Commercial fisheries are often perceived being in a state of decline and collapse, putting food

39 and economic security at risk. Such declines are frequently accompanied by contractions in

40 stock distribution, negative ecological impacts and diminishing economic benefits. Here we

41 present an example based on one of the world's most valuable and controversial fish species, 
42 bluefin tuna, which demonstates that effective management of both bluefin tuna and its prey has

43 been a key factor leading to a remarkable reoccupation of formerly lost habitat. This

44 reappearance, following decades of absence, occurred despite the bluefin tuna stock having had a

45 recent, long history of unsustainable and illegal exploitation. Marine ecological recovery actions can be successful, even in situations which may initially appear intractable.

Introduction:

50 Recovering the biomass and spatial range of depleted fish stocks is a challenge to fisheries

51 managers and conservation ecologists (1-3). Once lost, former biomasses and ranges often

52 disappear from human memory, thereby reducing motivation for and impairing recovery efforts

53 (4-6). Biomass and range recovery often take longer than anticipated, even when fishing is

54 reduced below sustainable levels, due to factors such as bycatch fishing mortality (i. e., captures

55 as bycatch in other fisheries), and changes in stock productivity $(1-3,7,8)$. Species that are

56 highly migratory and whose migrations take them into the high seas and multiple fishing

57 jurisdictions, such as tunas and billfishes, are potentially even more vulnerable to depletion and

58 prolonged recovery times than stocks under single or few fishery jurisdictions (2, 9).

59 Here we report a recovery of the former range of distribution by a highly migratory, highly

60 valuable, iconic top predator fish species (bluefin tuna, Thunnus thynnus). This species was the

61 target of unsustainable exploitation for many years in the 1990s-2000s, and its biomass declined

62 to record low levels in the late 2000s (10). As one of the world's most valuable fish species, it

63 has also been the subject of much scientific, public and conservation NGO scrutiny (11). 
Bluefin tuna spawn in sub-tropical regions (e.g., Mediterranean Sea) and then migrate north long

65 distances as adults to summer and autumn foraging areas $(12,13)$. In the northeast Atlantic,

66 historical adult foraging areas are located in the Bay of Biscay, on the northwest European

67 continental shelf off Ireland and the UK, and in the Norwegian Sea-North Sea-Skagerrak-

68 Kattegat-Øresund (the latter are hereafter referred to as northern European waters;

69 Supplementary Figure S1 showing ICES areas and sea names $(12,14))$. Bluefin tuna occupy

70 these waters in summer-early autumn before migrating southwards to overwintering areas. This

71 long-distance migratory behaviour is a part of the species' life-history, having evolved through

72 generations (13).

73 However, the migrations to northern European waters stopped almost completely in the early-

74 mid-1960s and bluefin tuna have been extremely rare in the area since the 1970s $(14,15)$; the

75 species has not supported commercial or recreational fisheries in the area since then (10)

76 (Supplementary Figure S2). The reasons for both the disappearance and the long period before

77 reappearance are unclear, but likely due to a combination of overexploitation of juveniles and

78 adults of both the tuna and their prey, and changing oceanographic conditions (14, 16-18).

79 We describe the re-appearance using citizen science data (i. e., observations from non-scientists

80 pursuing activities on or near the sea) and discuss possible reasons why it happened. Given the

81 high level of illegal and unsustainable exploitation of this species in the recent past (mid-late

82 1990s until ca. 2008-2010; (10)), the recovery of the habitat and range of this species is

83 extraordinary and could become a classic example of how recoveries can occur under a suitable

84 combination of fishery management reguations and ecosystem conditions. 
Bluefin tuna observations in 2015 and 2016:

87 We found and received many reports of bluefin tuna in the region. The observations are summarized in Figure 1 and Supplementary Table S2. The reports included observations of single individual tunas and of schools of various sizes from a few specimens (2-10) to hundreds.

90 The species is relatively easy to identify and distinguish in this area, mainly because of their

91 surface jumping behaviour, body shape, color and size. The sizes of tuna observed were usually

92 large (ca. $1.5-3 \mathrm{~m}$ ) and the jumping or surface-breaking behaviour is characteristic of this

93 species. All observations we present are based on individuals which are partially or entirely out

94 of the water due to jumping and surface swimming, which facilitated reliable identification; the 95 observations are supported in many cases by photographs or videos available on public social 96 media and angling or news media websites in Scandinavia. Some of these photographs are

97 shown as part of Figure 2 and as Supplementary Figure S3, and some online videos of bluefin tuna jumping are listed in Supplementary Table S3.

The locations of most of the sightings we obtained were in the central part of the eastern Skagerrak, along the Swedish west coast in the Skagerrak, and in the Kattegat (Figure 1). For example, recreational fishing tour boats and individual recreational fishermen and the Swedish

102 Coast Guard observed individual bluefin tuna swimming at the surface and jumping clear of the 103 water near a Swedish national marine park (Kosterhavet). The estimated sizes of these bluefin 104 tuna were 2-3 m. One bluefin tuna was caught by a Danish recreational angler north of Skagen, 105 Denmark in the Skagerrak on Sept. 19 and released alive after capture. This fish was measured in the water to be $3.03 \mathrm{~m}$ and estimated to weigh app. 400-450 kg (19). 
107

108

109

110

111

112

113

114

115

116

117

118

119

120

121

122

123

124

125

126

127

128

At nearly the same time (Sept. 17, 2016) and ca. 7 deg. latitude farther north, bluefin tuna were captured as part of a targeted commercial fishing operation in the Norwegian Sea, off Ona $\left(62.8603^{\circ} \mathrm{N} 6.5543^{\circ} \mathrm{E}\right)$, Møre, Norway, approximately halfway between Bergen and Trondheim. The tuna caught $(\mathrm{N}=190)$ each weighed ca. 170-300 kg (20-22). These tuna were captured by a Norwegian fishing vessel as part of the Norwegian bluefin tuna quota. Several Danish commercial fishermen, including one of the co-authors of this investigation (HSL), reported that they repeatedly saw schools in a localized area north of Skagen on several days during ca. two weeks in mid-late September, 2016; the total number of tunas observed on some days was in the hundreds. On Sept. 30, a school of 6-8 bluefin tuna were seen 200-250 m off the beach along the northern Danish Kattegat coast near Frederikshavn.

The first observation available to us in 2016 was made on August 12. A man in his sailboat, coming from the south through Øresund, observed a single tuna jumping out of the water four times, about 100 meters from his boat. The observation was made ca. 700-800 metres from the Danish coastline. The last observation reported to us was a sighting by a commercial fisherman in the Skagerrak on October 20. The cumulative amount of reports indicates that the species was present in large numbers for at least 2.5 months during late summer-autumn.

\section{Ecosystem conditions:}

The longest available time series of potential prey biomasses are from ICES stock assessments for herring and mackerel stocks in the North Sea, Norwegian Sea and northeast Atlantic. These show that the biomasses have been high since the late 1980s-early 1990s for the three stocks in the northeast Atlantic Ocean. The sum of the three biomasses has been at record-high levels since the early 2000s (Figure 3). 
129

130

131

132

133

134

135

136

137

138

139

140

141

142

143

144

145

146

147

148

149

150

At the smaller spatial scale of the Skagerrak-Kattegat, demersal research surveys in late summer-autumn show that catch rates (considered to be a relative indicator of biomass) for four potential prey species (herring, sprat, mackerel, anchovy) were relatively low in 2016. The most abundant of these species is usually herring; however its abundance peaked in 2011 and has declined to low levels since then, including in 2015 and 2016. Other demersal and the pelagic surveys also show that prey abundance in 2015 and 2016 was approximately average or even below-average (Supplmentary Figure S4).

August-October surface temperatures have been well above long-term average since 1994 when a significant regime shift occurred (STARS test; $\mathrm{P}<0.0001$ (31)); this shift is evident in the larger northeast Atlantic region and the Skagerrak-Kattegat sub-region where our tuna sightings have been made. However temperatures in 2015 and 2016 were not unusually warm compared to other years during the most recent regime.

\section{Discussion:}

Bluefin tuna appear to have re-discovered former foraging habitat in northern European waters, which they vacated about 40-50 years ago. The observations are identical to those reported in historical fishery reports, newspapers and scientific literature from the 1920s-1960s (Figure 2), when bluefin tuna were common in these waters (e. g., $(23,24)$ ); the jumping and surfacebreaking swimming behaviour is typical for bluefin tuna foraging on prey species $(23,25)$. Our observations indicate that bluefin tuna were abundant throughout the combined SkagerrakKattegat and coastal Norwegian Sea region. Since neither Denmark nor Sweden has a fishing quota, and there are no surveys potentially monitoring the distribution and abundance of bluefin tuna, the public observations are essential for providing evidence of their return to these waters. 
151 Cause of reappearance:

152 Given the long absence from the Skagerrak-Kattegat and neighboring waters, one must ask why

153 bluefin tuna has finally returned now. The factor which has likely contributed most to the return

154 is improved bluefin tuna fishery management since ca. the mid-late 2000s. Several changes were

155 made during this period, including reductions in quotas, increases in minimum landing sizes

156 from 6 to $10 \mathrm{~kg}$ and then to $30 \mathrm{~kg}$ so that a much larger share of juveniles can now survive long

157 enough to reach maturity (assumed to be at an age of 4 years, or ca. $25 \mathrm{~kg}$ (10)), improved catch

158 reporting requirements and documentation, and strengthened fishery surveillance and

159 enforcement $(10,11)$.

160 Prior to implementation of these changes, the stock was overexploited both legally (because

161 countries allocated themselves higher quota limits than those recommended by ICCAT

162 (International Commission for the Conservation of Atlantic Tunas) scientists as being

163 scientifically sustainable in the long term), and illegally (e. g., landings often exceeded the

164 biologically sustainable limits agreed by the countries during many years in the late 1990s and

165 early 2000s). Before the new regulations were implemented, historical exploitation of juveniles

166 in southern parts of the stock range was high since the 1950s and has been considered to be a

167 major factor leading to the disappearance and subsequent continued absence of bluefin tuna from

168 northern parts of the range (18). In addition, the parent stock biomass in the early-mid-2000s was

169 perceived to be declining (10) and at a rate that if continued could have met criteria for listing

170 this stock as “critically endangered” according to IUCN (International Union for the

171 Conservation of Nature) criteria (26). 
172 Implementation of the new fishery management regulations appears to have had positive effects.

173 Shortly after, several stock indicators of abundance started increasing, including the production

174 rate of new young bluefin tuna "recruits” $(10,11)$. As the stock has increased, bluefin tuna

175 appears to have expanded its migratory range, a pattern common among recovering fish stocks

$176(3,27)$, to explore new feeding habitats and to reduce density-dependent competition for prey,

177 including into some northern areas beyond formerly documented distribution ranges such as

178 Denmark Strait (east of Greenland (28)). This exploratory foraging behaviour may have led

179 them to return to the northern European shelf waters, where they apparently have found

180 sufficient prey for foraging.

181 A secondary reason for the return to these waters may be the relatively high biomasses of

182 potential energy-rich prey species such as mackerel, herring, and sprat. Herring and mackerel

183 dominate pelagic fish biomass in the region and their biomasses have recovered to or beyond

184 historical estimates (29). Some of these species (herring and mackerel) were also overexploited

185 in the 1950s-1970s leading to local collapses and fishery closures for these species. These

186 declines may have been a factor inhibiting earlier return of bluefin tuna to this region. However

187 following implementation of more sustainable fishing practices, the biomasses of these species

188 have recovered, but the tunas did not reappear in large numbers until several years after the prey

189 biomass recovered. This delay suggests that the main reason for the reappearance of bluefin

190 tuna in the region was the increase in tuna biomass itself, and the time required to re-learn

191 former migration pathways and foraging habitats $(17,30)$.

192 Moreover, as a large, fast-swimming schooling species with high daily energy intake, bluefin

193 tuna have high potential for quickly learning where prey concentrations are located. For

194 example, bluefin tuna have learned to follow or locate mackerel migrations to Iceland and east 
195 Greenland waters in the early 2010s and have been caught as bycatch in Greenlandic mackerel

196 fishing operations (28). It is likely therefore that if bluefin tuna had been more abundant in the

197 1990s and 2000s, they would have already appeared in high abundance in the Norwegian-North

198 Sea-Skagerrak-Kattegat area several years earlier than now.

199 Ocean temperature conditions are also known to affect tuna distributions and migrations (16, 31,

200 32), and have been generally warmer since 1994. However temperatures in 2015 or 2016 were

201 not exceptionally warm and were in fact colder than in some earlier years in the recent warm

202 regime (post-1994). Notably, bluefin tuna have been present in the Skagerrak-Kattegat during

203 many earlier years (e. g., 1920s-60s) when temperatures were lower than during the post-1994

204 regime (compare Figure 3 and Supplementary Figure S2), and have occupied colder areas farther

205 north in the past (e. g., in the Norwegian Sea and along the west Norwegian coast; see Ref.(24)

206 for temperature data). We conclude that temperatures in the Skagerrak-Kattegat or northeast

207 Atlantic region appear to have had little direct role on the re-appearance of bluefin tuna, although

208 they may have had indirect effects via changes in local food abundance, migration behaviour or

209 distribution. However the exact mechanisms by which temperature may have acted, if at all, are

210 unclear and remain speculative.

211 Appearances of bluefin tuna in other northern regions also suggest that the species range has

212 expanded, possibly due to its increased abundances. Bluefin tuna have appeared for the first

213 time known to science in waters north of its usual summer feeding range and entered the

214 Denmark Strait-Irminger Sea in 2012 (28). The entry of bluefin tuna in this region is likely due

215 to the higher tuna abundance, warmer temperatures in a habitat which formerly was close to or

216 colder than the lower tolerance limit for bluefin tuna, and large biomass of a key prey (mackerel)

217 (28), whose summer distribution has also been extending into these waters since the 2010s (33). 
218

219

220

221

222

223

224

225

226

227

228
In summary, both food and temperature conditions have been higher than average for many years before the tuna returned to the Skagerrak-Kattegat and probably also the wider North SeaNorwegian Sea-Skagerrak-Kattegat region. We consider it unlikely that either of these factors in 2015-2016 were the main direct drivers for the recent appearance of bluefin tuna in the Skagerrak-Kattegat region, although adequate prey and temperature conditions likely induced exploratory foraging bluefin tuna to remain in this region, once it was re-discovered.

Contribution of citizen science to bluefin tuna ecology:

For reasons explained above, our investigation relies on input from the public to document the species presence in this region. As with all citizen science reports, there is a possibility for some false, biased and otherwise incorrect reporting. We believe that such records are not likely present in our compilation because of the nearly simultaneous nature of the records over a wide area (e. g., the many sightings reported in the eastern Skagerrak-Kattegat on nearly the same day as the large commercial catch in central Norwegian coastal waters), the similarity of the reported behaviour to historical sightings of tuna in the region (e. g .,(23); see Figure 2 of main manuscript and Supplementary Figure S3) and the distinguishable features of bluefin tuna behaviour and size that reduce the likelihood of misidentification with other species.

Moreover, some of the reports were made by highly reputable observers, including on-duty officers of national coast guard services or by off-duty members of our research vessels while participating in recreational sea-based activities. Their observations and reports were identical to those made by other members of the public and by commercial and recreational fishermen targeting other species. For example, some fishermen observed tuna while trawling for pelagic fish (e. g., herring and mackerel) that are prey for bluefin tuna in this region. Lastly, several of 
240 the reports and our interviews via email or telephone include statements by the observers that

241

242

243

244

245

246

247

248

249

250

251

252

253

254

255

256

257

258

259

260

261

262

they had never seen such behaviour before despite years and even decades of activity on the sea and that they had knowledge of the species’ former presence in the area from older generations. We are confident therefore that our observations represent a valid and reliable source of documentary evidence of the presence of the species in these waters.

We are aware however that the reports based on citizen reporting reflect the spatial distribution of where the reporting observers were located. That is, they do not necessarily represent the full spatial distribution of where the tuna were located because (1) some tuna may have been observed in other areas, but not reported to us, (2) some tuna may have been present in other areas (and of course depths), but not seen by any human observers; and (3) observers were surely present over a much wider area than indicated by our few reports, but it is not possible to know which of those observers saw or did not see bluefin tuna. The spatial distribution of tuna based on our observations must therefore be interpreted cautiously, and we cannot exclude the possibility that bluefin tuna were present over a much wider area than is indicated by our data. We have tried to minimize such observer bias by making broad contact to the public and especially commercial fishermen (e. g., via their associations). Nevetheless, to obtain a more representative distribution in the area, alternative methods would need to be employed such as aerial surveying via airplanes (25, 34) or with drones (35) or tagging with electronic tags $(36,37)$ and subsequent modelling (30,38). In addition, increased public awareness of the species in the area and the need for its documentation could also increase public reporting of bluefin tuna observations and the reliability of distributional maps. Such combined survey- citizen science methods could also potentially be used to derive estimates of relative abundance in the region, which is not possible with our dataset. 
Future perspectives:

264 The return of bluefin tuna to northern European waters opens many new possibilities for both

265 scientific understanding of species biology/dynamics and for socio-economy. Regarding

266 science, a priority should be to investigate the migration behaviour and population origin of the

267 bluefin tunas which have appeared in these waters using a combination of modern tagging,

268 genetics, otolith and modelling methods. Bluefin tuna in the Atlantic are managed as two stocks

269 (western and eastern stocks, the latter including the Mediterranean) with separate quotas and 270 other regulations (10). Historically, bluefin tuna caught in the northern European region had

271 migrated both from the northeast and northwest Atlantic (12), and any future commercial or

272 recreational catches should be assigned to the correct stock. Such assignment would need for

273 example genetic or otolith-based evidence $(39,40)$.

274 New sustainable commercial and recreational fisheries would support and diversify local fishery

275 economies in primarily rural areas of the region. Furthermore, given the recent interest in the

276 general public for the return of this species to northern European waters $(41,42)$ (e. g., 5 video

277 clips made by citizen scientists have been viewed on social media > 270,000 times:

278 Supplementary Table S3), and the possibility that jumping bluefin tuna can be seen from

279 relatively small boats operating within minutes to a few hours of shore, there is potential that the

280 species could create and contribute to the eco-tourism industry.

281 A pre-requisite for realizing these scientific and socio-economic opportunities is that the recent

282 fishery management regulations for both bluefin tuna and their prey, and their compliance,

283 continues in future. In general, it presently appears as if efforts towards sustainable fishery

284 management both for the bluefin tuna and its prey species are having positive benefits for these 
285

286

287

288

289

290

291

292

293

294

295

296

297

298

299

300

301

302

303

304

305 General:

stocks. Should this be true, bluefin tuna may become a regular summer component of local fish communities and food webs, and contribute to small but lucrative commercial and recreational fisheries and eco-tourism economies.

The re-establishment of summer migration to this region, together with the recent increase in overall stock biomass, indicates that, as with some other recovering large iconic fish stocks (3), improved management, enforcement and compliance can yield positive benefits when ecosystem conditions for stock production are suitable $(3,7)$. These observations apply even for species such as bluefin tuna which has historically suffered from much illegal and over-fishing and whose highly migratory behaviour takes them into multiple fishing jurisdictions including international waters. The reappearance of bluefin tuna in the Skagerrak-Kattegat and neighboring seas serves as an example of the benefits of implementing effective recovery actions, despite a decades-long absence from the region and a highly unsustainable fisheries exploitation situation. In this case, implementation has not been too late to promote recovery. Similar efforts with other populations and species could also yield positive outcomes. These findings offer some optimism for the long-term recovery and sustainability of commerciallyexploited fish stocks, the ecosystems in which they live, and the economic sectors which they (could) support.

\section{Materials and Methods:}



former are available at higher spatial resolution for our region of interest.

Ecosystem conditions (e. g., local food concentrations, temperatures) are known to affect

As there are presently no commercial, recreational or scientific fisheries (surveys) for bluefin tuna in the Skagerrak-Kattegat, the only source of information available for documenting presence were reports from the public, including commercial and recreational fisher observations. We consider all these records to be "citizen science” and compiled observations from reports in newspapers, social media and via direct contact of the public with us. Details for the data compilation are available below. The observations were then organized chronologically, assigned a record number and visualized to display their spatial-temporal distribution. To place our work in the historical context of past fisheries for bluefin tuna in the region, we compiled and plotted officially reported landings data from ICES and other historical sources (summarized in (24)) for the years 1903-2014, which was the last year for which landings data are available from ICES. We use officially reported data from ICES instead of from ICCAT because the distributions of bluefin tuna $(16,28)$. We derived estimates of the inter-annual variability in abundance of major prey species and sea surface temperatures (i. e. those most likely experienced by bluefin tuna during summer foraging on the continental shelf) for the Northeast Atlantic to evaluate whether food and/or temperature conditions were unusually favorable in 2015 and 2016 compared to earlier years. Further details of the data sources and compilation are presented below.

\section{Bluefin tuna observations:}

We compiled observations of bluefin tuna from primarily public sources such as social media (i. e., Facebook, YouTube) and websites representing both commercial fishermen and anglers in 
Denmark and Sweden. We also obtained and used information sent to us by the public following announcements on the DTU Aqua website and sent to Danish commercial and sportsfishermens' organizations and contact by SLU Aqua with Swedish sportsfishermen that we were interested in receiving sighting observations. We supplemented these citizen science observations with reports of commercial catches and bycatches in the Norwegian Sea, North Sea, Skagerrak, Kattegat and Øresund. The time period covered was August-October 2016. However during the course of this data collection, we also received or found reports of observations in 2015 which we used to support our overall results and conclusions. In many cases, the sightings were supported by photographs or video recordings of bluefin tuna. The information provided by members of the public included date and location of the observation, how many bluefin tuna were observed (e. g., single individual, school, approximate number of schools and number of fish per school), behaviour (jumping over water surface, breaking water surface), and prey escape behaviours observed at the surface. The observations were entered into a database and visualized geographically to illustrate their spatial distribution in relation to distance from land, bottom topography and sea surface temperature.

Estimates of abundance of potential prey for bluefin tuna:

We estimated abundances of potential prey for bluefin tuna in the region from regional stock assessments for main prey species and from fishery research vessel surveys. We used the North Sea herring, Norwegian spring-spawning herring and Northeast Atlantic mackerel total stock biomass estimates from the ICES assessments as indicators of potential prey for bluefin tuna in the region of our study. These stocks occupy large areas (see ICES stock management area map, Supplementary Figure S1), which overlap with the historical distribution of bluefin tuna in the region $(12,14,15,24)$; moreover tuna which enter the Skagerrak and Kattegat historically 
351 passed through the northern North Sea and Norwegian Sea on their way to this region $(12,15)$

352 and would potentially encounter these prey during the migration and while foraging for prey.

353 These biomass estimates are based on stock assessments of the various stocks (29).

354 We also used scientific research vessel surveys to estimate prey abundances more locally in the 355 Skagerrak-Kattegat and where bluefin tuna were observed in 2015 and 2016. Hydro-acoustic 356 and bottom trawl surveys are conducted annually in the region as part of population status

357 monitoring in the region for fisheries management purposes (43-46). The surveys are conducted 358 in February-March (demersal survey in Kattegat-Belt Sea), late June-early July (hydro-acoustic 359 pelagic survey in Skagerrak-Kattegat), and August-September (demersal survey in Skagerrak360 Kattegat). The three surveys when considered in aggregate provide information about the 361 relative abundance of potential prey (herring, sprat, mackerel) among years. The demersal 362 survey in August-September is conducted when bluefin tuna were present in our area and we 363 present its results in the main article; survey estimates at other times of year are presented as 364 Supplementary Information.

365 The main characteristics of the surveys (depth sampled, geographic location, year and seasonal 366 coverage) are summarized in Supplementary Table S1. The notable feature for all the surveys is

367 that sampling methods and gear within each survey are the same throughout the time periods 368 shown here (43-46). As seen in the Table, only the acoustic survey is directly designed to 369 estimate abundance and biomass of pelagic fish species (e. g., herring, sprat); this survey is used 370 as input to ICES stock assessments for herring in the western Baltic Sea and in the North Sea 371 (43). The other two surveys are designed to capture demersal fish species as part of the 372 International Bottom Trawl Survey (IBTS) (47) and Baltic International Trawl Survey (BITS)

373 (44). However these surveys regularly capture pelagic fish species, including herring and sprat, 
and these data can indicate relative trends and fluctuations in biomass, even though they may not necessarily represent true abundances due to lower catchability for pelagic fishes which are distributed higher in the water column than the demersal sampling gear. For the acoustic survey, we use the total abundances of all size groups estimated on the survey in specific strata of the survey (i. e., Kattegat, and waters along the Swedish west coast in the northeastern part of the Skagerrak (45)). For the demersal surveys, we calculated annual geometric means of catch-perunit-effort (CPUE) using biomass/trawl hour as a relative biomass metric. Full details of the survey methods and sampling gear are available in literature (43-46, 48).

Estimation of sea surface temperature:

Bluefin tuna occupy mainly surface waters (i. e., above the seasonal thermocline) when feeding on continental shelves in summer as in the region of our study. This habitat is also the depth layer predominantly occupied by their main prey (e. g., herring, sprat, and mackerel) in the region. We assumed that sea surface temperature (SST) as estimated by satellite imagery is an approximate indicator of the temperatures available for and experienced by bluefin tuna while foraging in the region.

We calculated the average SST for the region for the months of August, September and October for the time period 1870-2016 using a large international database of in situ and satellite-derived observations(49) available online (http://wps-web1.ceda.ac.uk/ui/home) at 1 degree monthly resolution. This time series allowed us to evaluate whether 2015 and 2016 were exceptionally warm summers relative to historical variability and trends. We calculated mean temperatures for both the Skagerrak-Kattegat $\left(8^{\circ}-13^{\circ} \mathrm{E} ; 55^{\circ}-59^{\circ} \mathrm{N}\right)$ and a larger area of the northeast Atlantic Ocean $\left(20^{\circ} \mathrm{W}-13^{\circ} \mathrm{E} ; 50^{\circ}-66^{\circ} \mathrm{N}\right)$ through which bluefin tuna migrate when entering the 
Norwegian-North Sea-Skagerrak-Kattegat. We evaluated whether regime shifts in temperature occurred using the STARS algorithm (50); settings used for testing were Huber parameter = 1 and series length $=10$. Higher resolution (0.05 degree daily) satellite-based estimates of SST (51) in the Skagerrak and Kattegat region were averaged temporally over the main period where tuna were observed (7th - 21st September 2016) and used to characterize the thermal environment in which the fish were observed.

Acknowledgments: We thank Jeppe Olesen for GIS and mapping expertise and members of the public without whom this investigation could not have been possible. The work was partly supported by the Nordic Council of Ministers (project no. 141-2016-Tuna; NordTun) and has been conducted using MyOcean Products.

\section{References:}

1. Worm B, et al. (2009) Rebuilding global fisheries. Science (80- ) 325:578-585.

2. Murawski SA (2010) Rebuilding depleted fish stocks: the good, the bad, and, mostly, the ugly. ICES J Mar Sci J du Cons 67(9):1830-1840.

3. Rose GA, Rowe S (2015) Northern cod comeback. Can J Fish Aquat Sci 72(12):1789_ 1798.

4. Pauly D (1995) Anecdotes and shifting baseline syndrome of fisheries. Trends Ecol Evol 10:430.

5. Jackson JBC, et al. (2001) Historical overfishing and the recent collapse of coastal 
ecosystems. Science (80- ) 293:629-638.

418

419

420

421

422

423

424

425

426

427

428

429

430

431

432

433

434

435

436

437

438

6. Lotze HK (2014) Lessons from historical ecology and management. The Sea; Vol. 16: Marine Ecosystem-Based Management (568 Pp.), eds Fogarty M, McCarthy JJ (Harvard University Press, Cambridge, MA), pp 16-55.

7. Britten GL, Dowd M, Kanary L, Worm B (2017) Extended fisheries recovery timelines in a changing environment. Nat Commun 8:15325.

8. Szuwalski CS, Vert-Pre KA, Punt AE, Branch TA, Hilborn R (2015) Examining common assumptions about recruitment: a meta-analysis of recruitment dynamics for worldwide marine fisheries. Fish Fish 16(4):633-648.

9. Cullis-Suzuki S, Pauly D (2010) Failing the high seas: A global evaluation of regional fisheries management organizations. Mar Policy 34(5):1036-1042.

10. ICCAT (2014) Report of the 2014 Atlantic bluefin tuna stock assessment session, Madrid, Spain, September 22-27, 2014 (www.iccat.org) (ICCAT, Madrid, Spain).

11. Fromentin J-M, Bonhommeau S, Arrizabalaga H, Kell LT (2014) The spectre of uncertainty in management of exploited fish stocks: The illustrative case of Atlantic bluefin tuna. Mar Policy 47:8-14.

12. Mather FJ, Mason JM, Jones AC (1995) Historical document: life history and fisheries of Atlantic bluefin tuna. NOAA Tech Memo NMFS-SEFSC 370:1-165.

13. Cury P, Anneville O, Bard FX, Fonteneau A, Roy C (1998) Obstinate north Atlantic bluefin tuna (Thunnus thynnus thynnus): an evolutionary perspective to consider spawning migration. ICCAT CollVolSciPapers (Proc.of ICCAT Tuna Symp 1998, Part 1) 50:239-247. 
14. Fromentin JM (2009) Lessons from the past: investigating historical data from bluefin tuna fisheries. Fish Fish 10(2):197-216.

441 15. Tiews K (1978) On the disappearance of bluefin tuna in the North Sea and its ecological implications for herring and mackerel. RappP-vReunCons.intExplorMer 172:301-309.

443 16. Fromentin J-M, Reygondeau G, Bonhommeau S, Beaugrand G (2013) Oceanographic changes and exploitation drive the spatio-temporal dynamics of Atlantic bluefin tuna (Thunnus thynnus). Fish Oceanogr 23:147-156.

17. De Luca G, Mariani P, MacKenzie BR, Marsili M (2014) Fishing out collective memory of migratory schools. J R Soc Interface 11 (2014):1-7.

18. Cort JL, Abaunza P (2015) The Fall of the Tuna Traps and the Collapse of the Atlantic Fish Sci Aquac 23(4):346-373.

19. Bursell J (2016) 400 kilo+ tun genudsat i dansk farvand. Fisk og Fri. Available at: http://www.fiskogfri.dk/ [Accessed September 23, 2016].

20. Aarøy TA (2016) Fikk 190 makrellstørjer på en gang. Sysla (online newspaper). Available at: http://sysla.no/2016/09/17/havbruk/fikk-190-makrellstorjer-pa-en-gang_157057/.

455 21. Tangen M (2016) Hillersøy med storkast for makrelstørje (English: The fishing vessel Hillersøy with a big catch of bluefin tuna). Kystbloggen.com. Available at: http://www.webinntekt.com/blogg/?p=1534 [Accessed January 6, 2017]. at: https://www.youtube.com/watch?v=eXGZ4nUhk6w. 
$46124 . \quad$ MacKenzie BR, Myers RA (2007) The development of the northern European fishery for north Atlantic bluefin tuna (Thunnus thynnus) during 1900-1950. Fish Res 87:229-239 (doi:10.1016/j.fishres.2007.01.013).

25. Bauer R, Bonhommeau S, Brisset B, Fromentin J (2015) Aerial surveys to monitor bluefin tuna abundance and track efficiency of management measures. Mar Ecol Prog Ser 534:221-234.

26. MacKenzie BR, Mosegaard H, Rosenberg AA (2009) Impending collapse of bluefin tuna in the northeast Atlantic and Mediterranean. Conserv Lett 2(1):26-35.

469 27. Worm B, Tittensor DP (2011) Range contraction in large pelagic predators. Proc Natl Acad Sci U S A 108(29):11942-11947.

471 28. MacKenzie BR, Payne MR, Boje J, Hoyer JL, Siegstad H (2014) A cascade of warming impacts brings bluefin tuna to Greenland waters. Glob Chang Biol 20(8):2484-2491.

29. ICES (2016) Report of the ICES Advisory Committee. ICES Advice - Books 1-10. (Copenhagen, Denmark).

475 30. Mariani P, Křivan V, MacKenzie BR, Mullon C (2015) The migration game in habitat network: the case of tuna. Theor Ecol 9(2):219-232.

477 31. Dufour F, Arrizabalaga H, Irigoien X, Santiago J (2007) Climate impacts on albacore and bluefin tunas migrations phenology and spatial distribution. Prog Oceanogr 86(1-2):283290. ecological niche approach. Prog Oceanogr 142:30-46. 
benefits a national economy. Ecol Appl. doi:10.1002/eap.1384.

484

485

486

487

488

489

490

491

492

493

494

495

496

497

498

499

500

501

502
34. Lutcavage M, Kraus S, Hoggard W (1997) Aerial survey of giant bluefin tuna, Thunnus thynnus, in the great Bahama Bank, Straits of Florida, 1995. Fish Bull 95(2):300-310.

35. Kiszka J, Mourier J, Gastrich K, Heithaus M (2016) Using unmanned aerial vehicles (UAVs) to investigate shark and ray densities in a shallow coral lagoon. Mar Ecol Prog Ser 560:237-242.

36. Wilson SG, et al. (2015) Tracking the fidelity of Atlantic bluefin tuna released in Canadian waters to the Gulf of Mexico spawning grounds. Can J Fish Aquat Sci 72(11):1700-1717.

37. Richardson DE, et al. (2016) Discovery of a spawning ground reveals diverse migration strategies in Atlantic bluefin tuna (Thunnus thynnus). Proc Natl Acad Sci U S A 113(12):3299-304.

38. Chapman EW, Jorgensen C, Lutcavage ME (2011) Atlantic bluefin tuna (Thunnus thynnus): a state-dependent energy allocation model for growth, maturation, and reproductive investment. Can J Fish Aquat Sci 68(11):1934-1951.

39. Kumar G, Kocour M (2015) Population Genetic Structure of Tunas Inferred from Molecular Markers: A Review. Rev Fish Sci Aquac 23(1):72-89.

40. Rooker J, et al. (2014) Crossing the line: migratory and homing behaviors of Atlantic bluefin tuna. Mar Ecol Prog Ser 504:265-276.

41. Christiansen M, Gyldenkræne P (2016) Nordjysk lystfisker jubler: der er blåfinnede tun overalt. Danmarks Radio Nyheder. Available at: http://www.dr.dk/nyheder/indland/nordjysk-lystfisker-jubler-der-er-blaafinnede-tun- 
overalt [Accessed September 26, 2016].

506

507

508

509

510

511

512

513

514

515

516

517

518

519

520

521

522

523

524

525

526

42. Fjeldseth $\varnothing$ (2016) Vil ha sportsfiske etter størje. NJFF Nyheter (Norges Jeger- og Fisk ; Nor Hunt Sportfish Assoc. Available at: https://www.njff.no/nyheter/Sider/NJFF-vil-hasportsfiske-etter-storje.aspx.

43. ICES (2016) First interim report of the ICES Working Group on International Pelagic Surveys (WGIPS) (Copenhagen) Available at: www.ices.dk.

44. ICES (2016) Second interim report of the Baltic International Fish Survey Working Group (WGBIFS), 30 March - 3 April, 2016, Rostock, Germany. ICES C 2016/SSGIEOM 07:1597.

45. Stæhr K-J (2016) Acoustic herring survey report for RV “Dana” 2nd June - 5th July, 2016 (Charlottenlund, Denmark).

46. Eigaard OR, Støttrup JG, Hofmann E, Hovgård H (2003) DFU’s standardtrawl: konstruction og sammenlignende fiskeri (DFU-rapport No. 126-03) (in Danish) (Charlottenlund, Denmark).

47. ICES (2012) Manual for the International Bottom Trawl Surveys. Series of ICES Survey Protocols. SISP 1-IBTS VIII (Copenhagen, Denmark) Available at: www.ices.dk.

48. ICES (2013) Manual for the Baltic International Trawl Surveys (BITS) - Addendum 1: WGBIFS BITS Manual 2013 (Copenhagen, Denmark) Available at: www.ices.dk.

49. Rayner NA, et al. (2003) Global analyses of sea surface temperature, sea ice and night marine air temperature since the late nineteenth century. JGeophysRes 108:4407-doi: 10.1029/2002JD002670 (updates available.

50. Rodionov S, Overland J (2005) Application of a sequential regime shift detection method 
to the Bering Sea ecosystem. ICES J Mar Sci 62(3):328-332.

528 51. Donlon CJ, et al. (2012) The Operational Sea Surface Temperature and Sea Ice Analysis (OSTIA) system. Remote Sens Environ 116:140-158.

52. ICES (2016) ICES Advice (International Council for the Exploration of the Sea, Copenhagen, Denmark).

\section{Figure legends (figures are located after legends):}

Figure 1. Locations where individual or schools of bluefin tuna were observed in Skagerrak-

537 Kattegat-Øresund in 2015 and 2016. Numbers beside observations correspond to records in

538 Table S1. Colour contours: averaged sea surface temperature as derived from satellite imagery

539 (51) during Sept. 7-21, 2016. Black contour lines: bottom topography. Red box on main map

540 shows where one of the authors (HSL) saw hundreds of bluefin tuna in schools during several

541 days centred on Sept. 22, 2016. Red star on inset map: location where 190 bluefin tuna were

542 captured on Sept. 17, 2016 in one haul by a Norwegian commercial fishing boat (21).

543 Figure 2. Photographic documentation of presence and jumping behaviour of bluefin tuna in the

544 Skagerrak and Kattegat in a historical period (1947 (23)) and in 2016 (four lower photographs).

545 The photographs 3-6 correspond to observation numbers 8, 11, 6 and 11 respectively in Table

546 S2. The historical photographs illustrate the similarity of historical bluefin tuna size, shape and

547 behaviour with that observed in 2016. Additional photographs and links to web-based video 
548 clips on social media are available in Supplementary Figure S3 and Table S3. All images are

549 reproduced with permission from photographers.

550 Figure 3. Indicators of potential prey biomass and temperature conditions in the Skagerrak-

551 Kattegat and neighboring regions. A: interannual variability in total stock biomass of key prey

552 species (and their sum) for bluefin tuna in northern European continental shelf regions. The

553 stocks are autumn-spawning herring in the North Sea, spring-spawning herring in the

554 Norwegian-Barents Sea, and mackerel in the northeast Atlantic (52). B: mean ln CPUE (ln

$555 \mathrm{~kg}$ /hour $+0.001 ; \pm 2 \mathrm{x}$ standard error) for herring, sprat, mackerel and anchovy in the Skagerrak-

556 Kattegat during August-September research vessel surveys. C: inter-annual variability in late

557 summer-autumn (mean of August, September and October) sea surface temperature in the

558 Skagerrak-Kattegat and a larger area of the northeast Atlantic $\left(20^{\circ} \mathrm{W}-13^{\circ} \mathrm{E} ; 50^{\circ}-66^{\circ} \mathrm{N}\right)$ for

559 1870-2016 (black solid line with dots and black dashed line with squares) and regime-specific

560 mean temperatures (red: Skagerrak-Kattegat; blue: northeast Atlantic) for different statistically

561 significant regimes (50). Data source: Hadley Climate Research Unit, UK (49)). 
bioRxiv preprint doi: https://doi.org/10.1101/197780; this version posted October 4, 2017. The copyright holder for this preprint (which was not certified by peer review) is the author/funder, who has granted bioRxiv a license to display the preprint in perpetuity. It is made available under aCC-BY-NC-ND 4.0 International license.

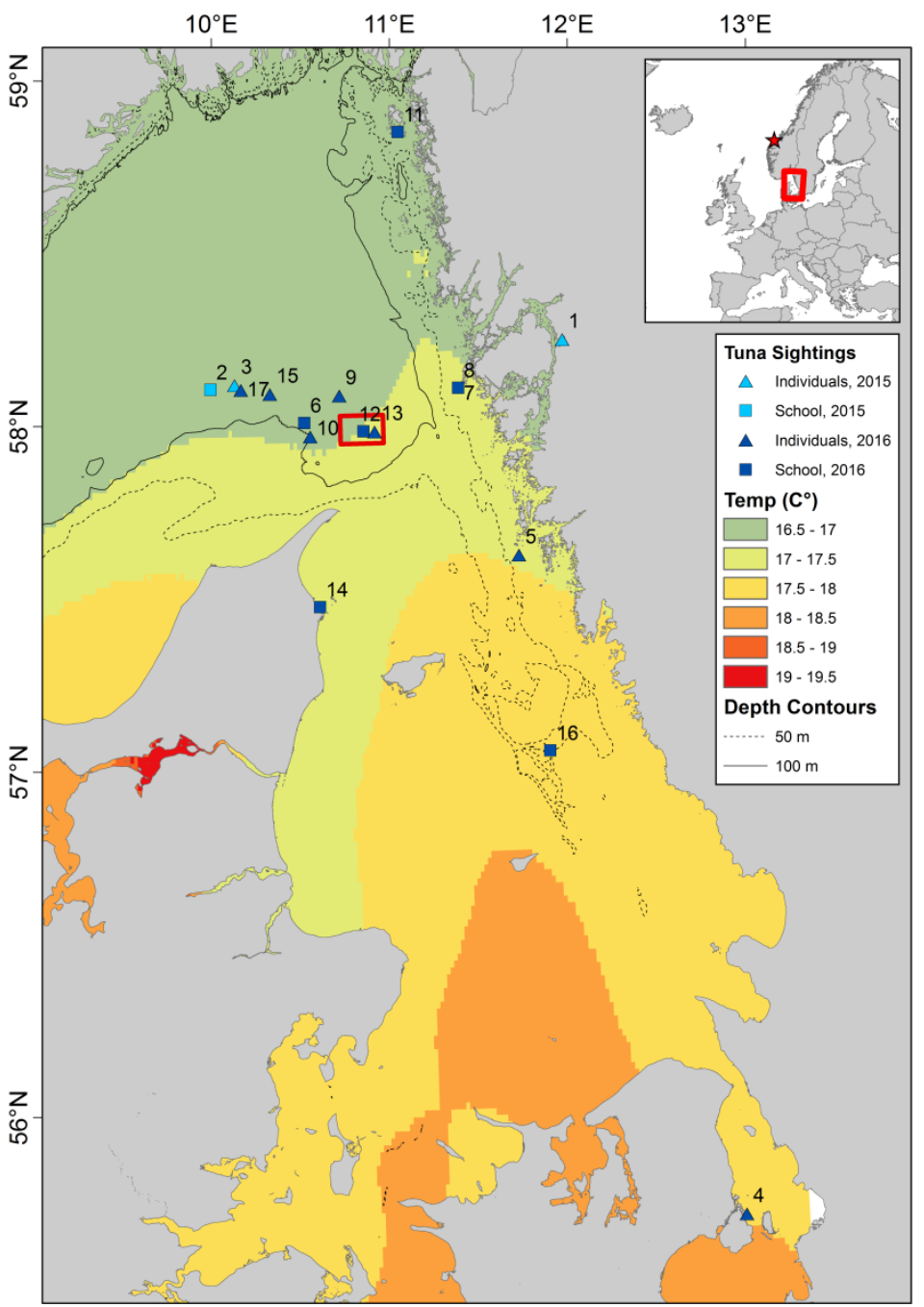

565

Figure 1. 
bioRxiv preprint doi: https://doi.org/10.1101/197780; this version posted October 4, 2017. The copyright holder for this preprint (which was not certified by peer review) is the author/funder, who has granted bioRxiv a license to display the preprint in perpetuity. It is made available under aCC-BY-NC-ND 4.0 International license.
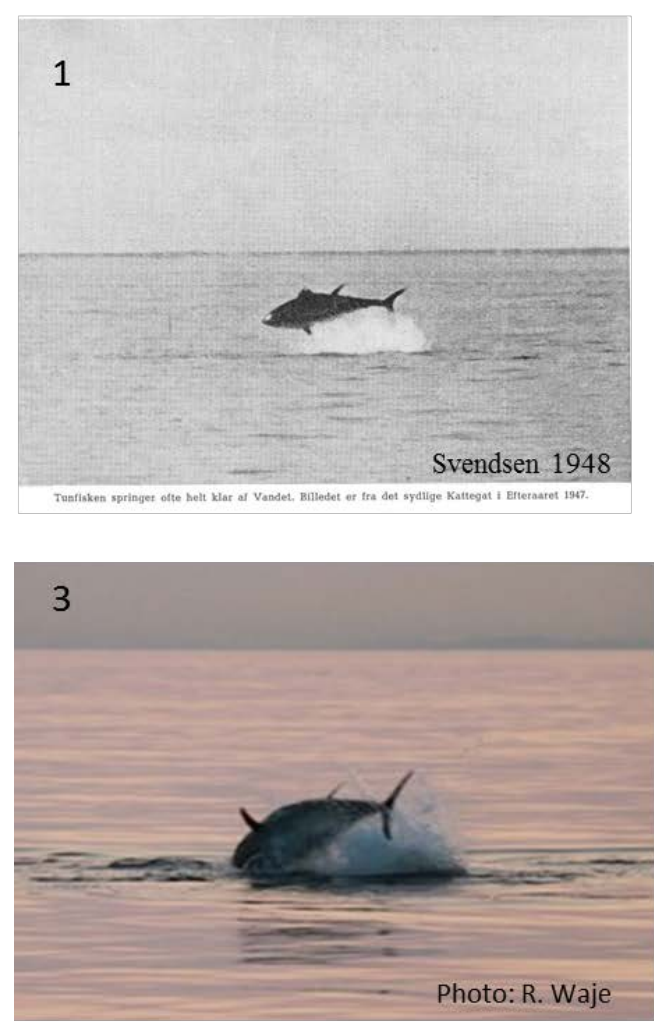

5

567

568

Video: J. Wolner

Figure 2.
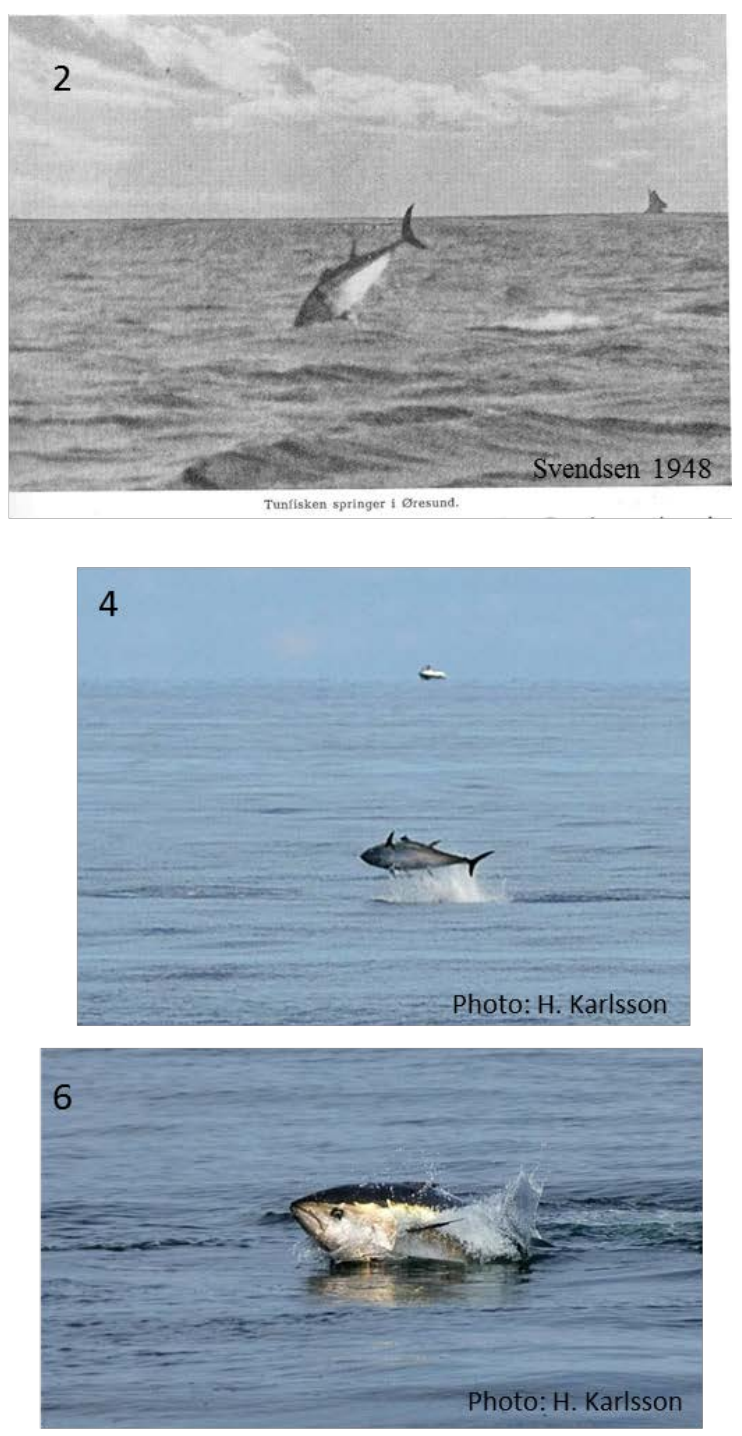

6 
bioRxiv preprint doi: https://doi.org/10.1101/197780; this version posted October 4, 2017. The copyright holder for this preprint (which was not certified by peer review) is the author/funder, who has granted bioRxiv a license to display the preprint in perpetuity. It is made available under
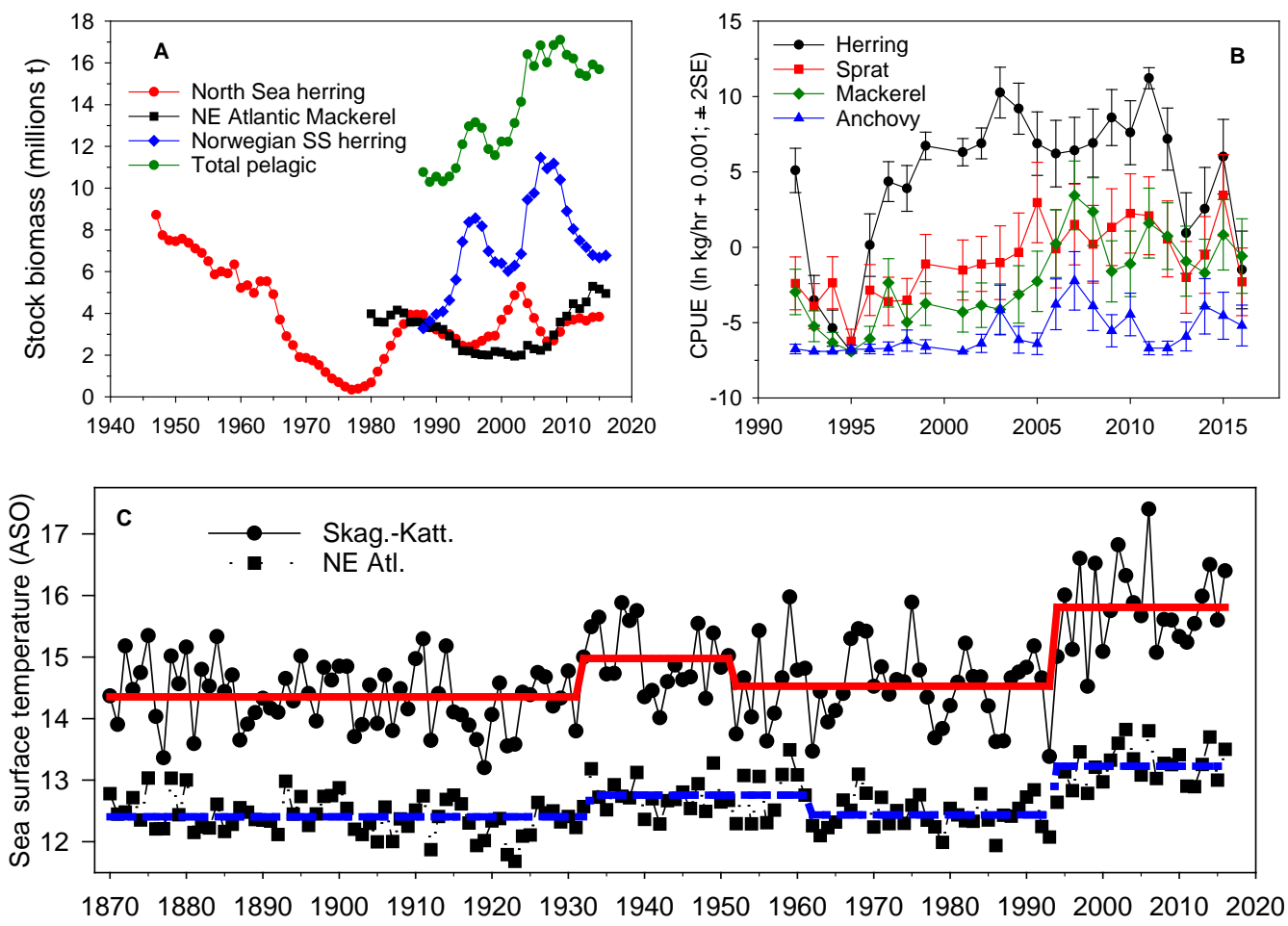

Figure 3. 
bioRxiv preprint doi: https://doi.org/10.1101/197780; this version posted October 4, 2017 . The copyright holder for this preprint (which was not certified by peer review) is the author/funder, who has granted bioRxiv a license to display the preprint in perpetuity. It is made available under aCC-BY-NC-ND 4.0 International license.

572 Supplementary Materials:

573

574 Supplementary Figures:

575 Figure S1. ICES fishery stock management areas.

576

577

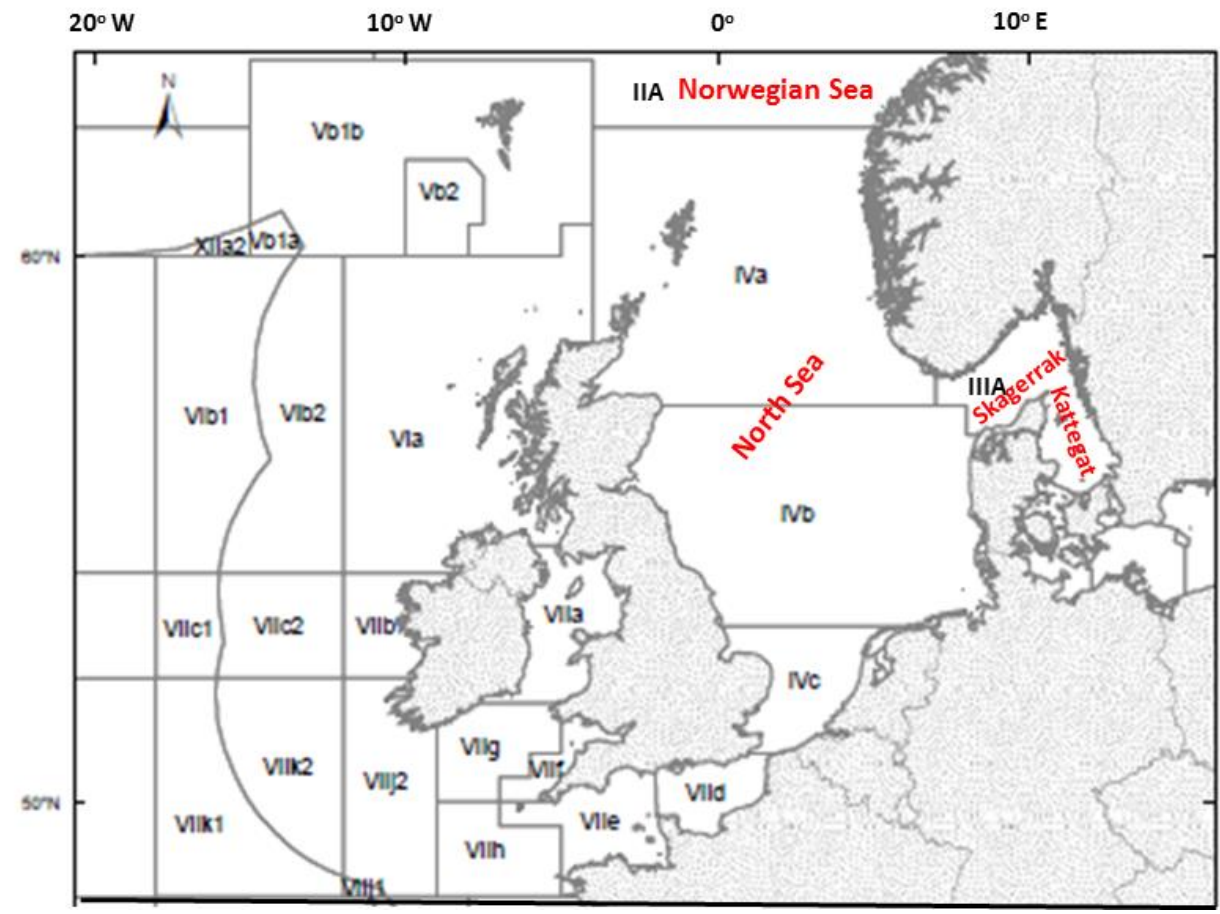

578 
580 Figure S2. Reported catches of bluefin tuna in ICES areas II, III and IV corresponding

581 approximately to respectively the Norwegian Sea, North Sea, and Skagerrak-Kattegat-Øresund

582 (see Figure S1 for map of ICES stock management areas). Catch data officially reported to ICES

583 from 1903-2014 are from ICES databases available online (www.ices.dk). Additional catch data

584 from before 1927 were compiled from historical fishery reports, catch records, museum records

585 and other documents as summarized in (24).

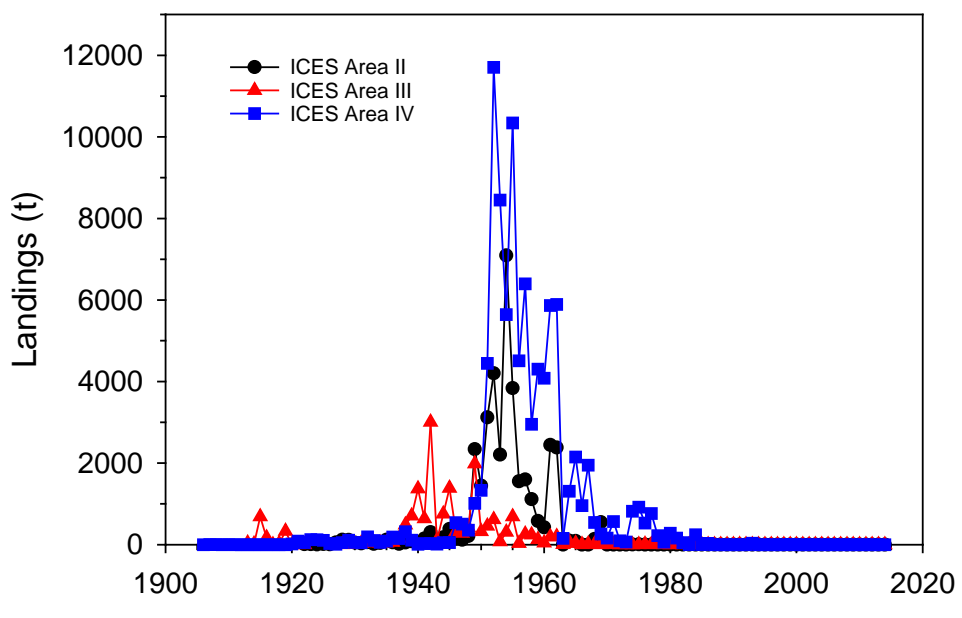


bioRxiv preprint doi: https://doi.org/10.1101/197780; this version posted October 4, 2017. The copyright holder for this preprint (which was not certified by peer review) is the author/funder, who has granted bioRxiv a license to display the preprint in perpetuity. It is made available under aCC-BY-NC-ND 4.0 International license.

588 Figure S3. Photographs showing bluefin tuna in the Skagerrak-Kattegat during September 2016.

589 Photos provided with permission by members of the public. Collage 1: R. Waje, collage 2: $\mathrm{H}$.

590 Karlsson, collage 3: J. Wolner.
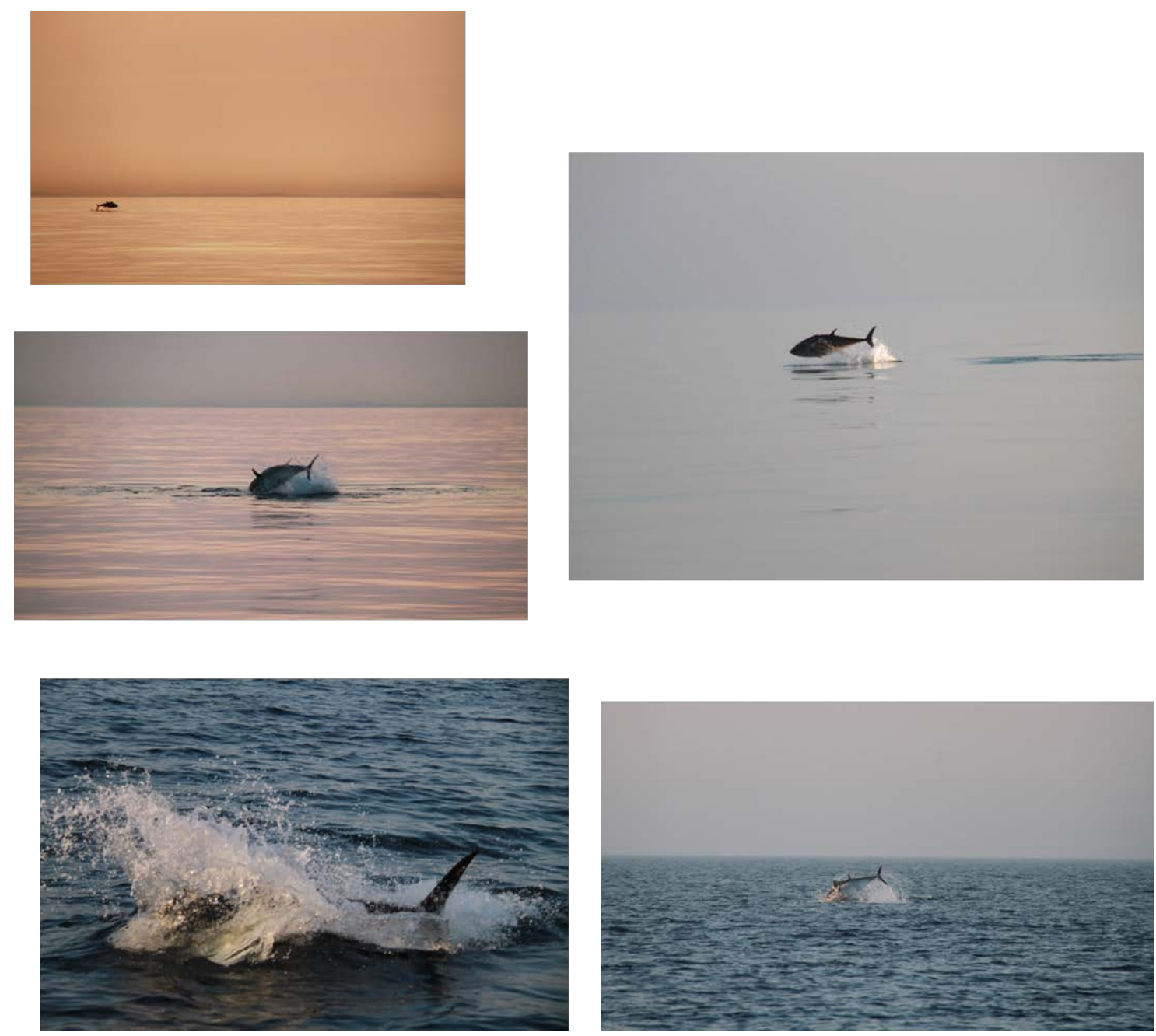

592 Collage 1 - R. Waje. 
bioRxiv preprint doi: https://doi.org/10.1101/197780; this version posted October 4, 2017. The copyright holder for this preprint (which was not certified by peer review) is the author/funder, who has granted bioRxiv a license to display the preprint in perpetuity. It is made available under aCC-BY-NC-ND 4.0 International license.
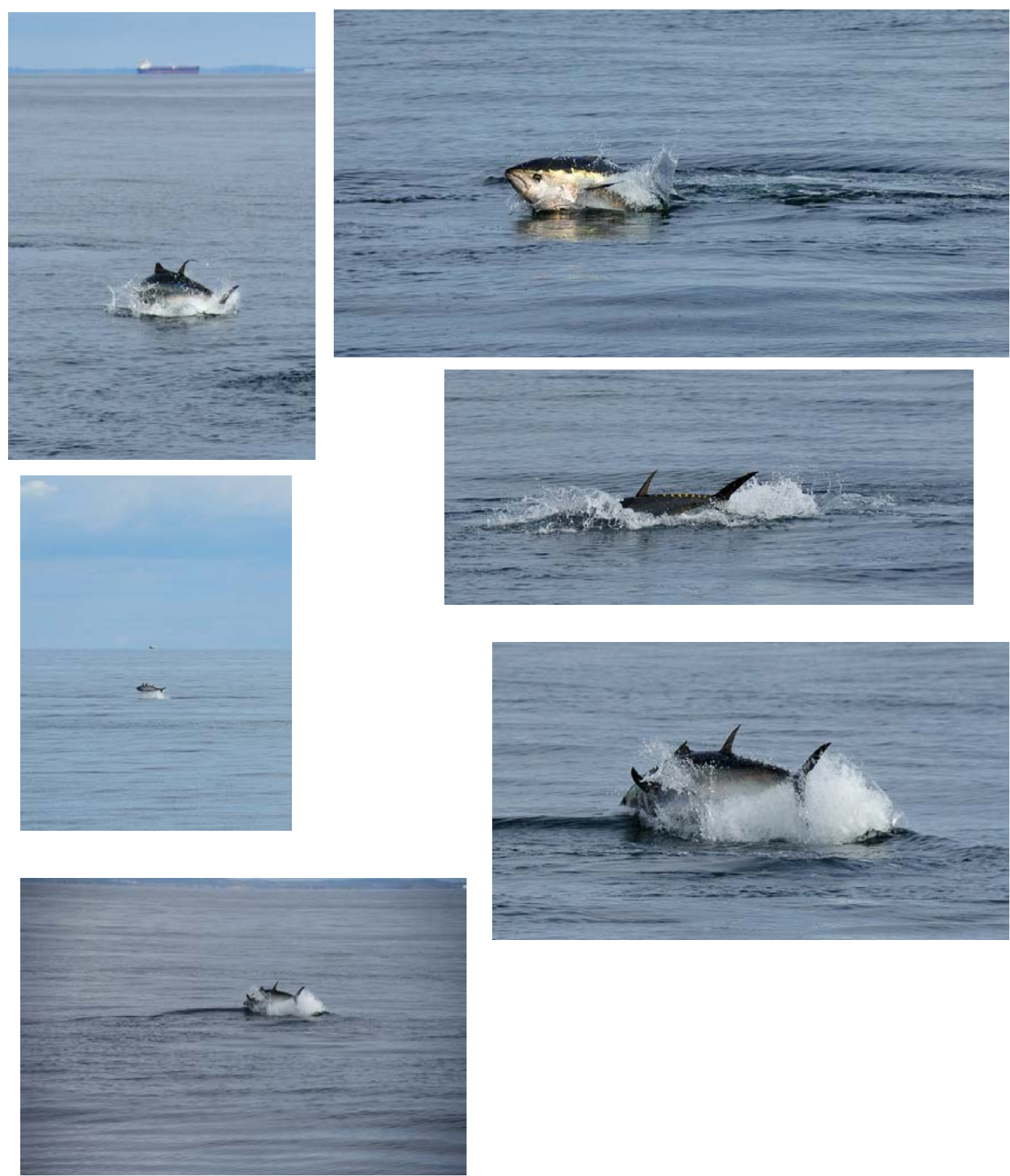
bioRxiv preprint doi: https://doi.org/10.1101/197780; this version posted October 4, 2017. The copyright holder for this preprint (which was not certified by peer review) is the author/funder, who has granted bioRxiv a license to display the preprint in perpetuity. It is made available under aCC-BY-NC-ND 4.0 International license.
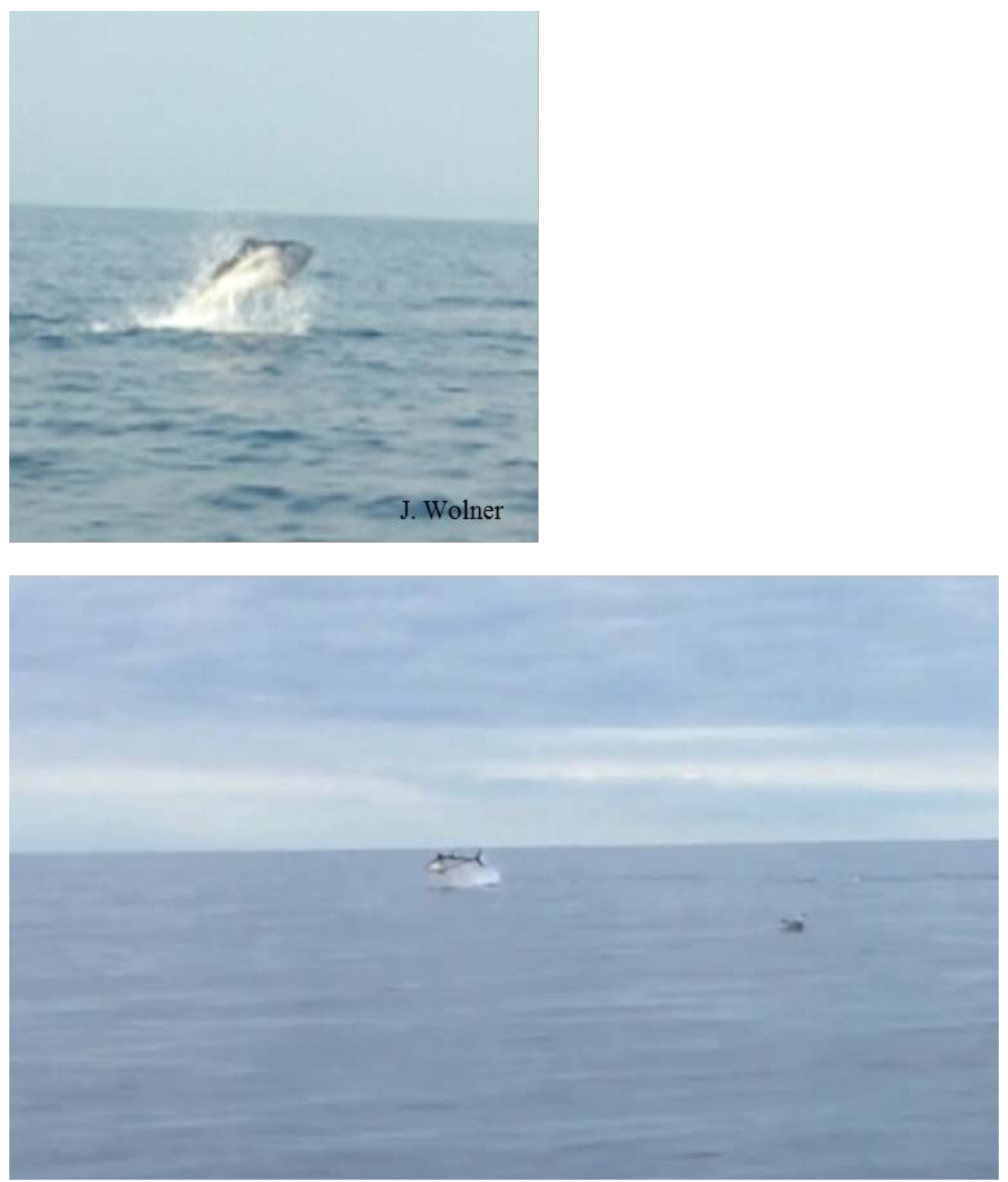

598 Collage 3: J. Wolner 
601 Figure S4. A: mean ln CPUE (ln kg/hour + 0.001; \pm 2 x standard error) for herring, sprat and

602 anchovy in autumn (late October-early November) research trawl surveys in Kattegat-Øresund-

603 Belt Sea (north of 55 N.) during 1994-2016. B: estimates of prey biomass as derived from

604 research vessel hydro-acoustic surveys in the Skagerrak-Kattegat-Øresund during 2008-2016

605 (see Table S1 for survey details).
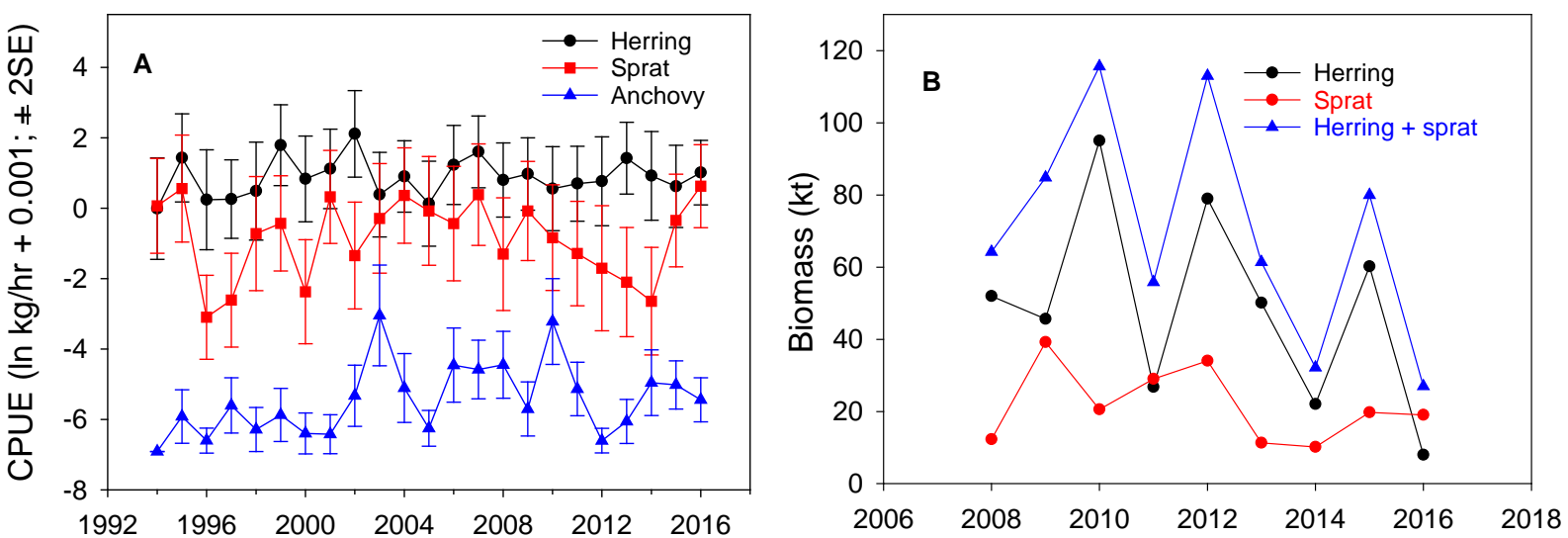


\section{Supplementary Tables:}

612 Table S1. Overview of research vessel surveys which provided estimates of biomass of potential

613 prey for bluefin tuna in the Skagerrak-Kattegat-Øresund. The surveys are part of international

614 bottom-trawl and acoustic surveys in the region designed and coordinated internationally by

615 ICES.

\begin{tabular}{|c|c|c|c|}
\hline \multirow[t]{2}{*}{ Characcteristic } & \multicolumn{3}{|c|}{ Survey vessel } \\
\hline & $\begin{array}{l}\text { RV Havfisken } \\
\text { (Denmark) }\end{array}$ & RV Dana (Denmark) & RV Argos (Sweden) \\
\hline Sampling gear & Demersal trawl & $\begin{array}{l}\text { Hydro-acoustics } \\
\text { with pelagic and } \\
\text { demersal } \\
\text { calibration trawls }\end{array}$ & Demersal trawl \\
\hline Year coverage & $\begin{array}{l}\text { 1994-2016 } \\
\text { (October- } \\
\text { November) }\end{array}$ & $2008-2016$ & $\begin{array}{l}\text { 1992-2016 (August- } \\
\text { September) }\end{array}$ \\
\hline Location & $\begin{array}{l}\text { Kattegat, } \emptyset \text { resund, } \\
\text { Belt Sea north of } 55 \\
\text { N. }\end{array}$ & Skagerrak, Kattegat & Skagerrak, Kattegat \\
\hline Target species & $\begin{array}{l}\text { Demersal fish } \\
\text { community }\end{array}$ & Herring and sprat & $\begin{array}{l}\text { Demersal fish } \\
\text { community }\end{array}$ \\
\hline
\end{tabular}

616 
618 Table S2. Observational data for sightings of bluefin tuna individuals and schools in the

619 Skagerrak, Kattegat and Øresund during 2015 and 2016. The data were recorded by members of

620 the public (“citizen scientists”). The observation record numbers correspond to the sightings

621 displayed visually in the map in Figure 1 of the main manuscript. Observers' identities are

622 known to the authors.

\begin{tabular}{|c|c|c|c|c|c|}
\hline $\begin{array}{l}\text { Obs. } \\
\text { ID no. }\end{array}$ & Date & Latitude & Longitude & Approx. Number of individuals & $\begin{array}{l}\text { School or } \\
\text { Individuals? }\end{array}$ \\
\hline 1 & Aug. 7, 2015 & 58.21947 & 11.90087 & 1 & Individuals \\
\hline 2 & Sept. 10, 2015 & 58.103 & 9.967 & $\begin{array}{l}\text { several schools, with individuals } \\
\text { jumping. Probably ca. } 1000 \text { tuna in } \\
\text { total. }\end{array}$ & School \\
\hline 3 & Sept. 21, 2015 & 58.0994 & 10.1363 & 2 & Individuals \\
\hline 4 & Aug. 12, 2016 & 55.66719 & 12.65734 & 1 & Individuals \\
\hline 5 & Aug. 21, 2016 & 57.60167 & 11.61889 & 1 & Individuals \\
\hline 6 & Sept. 13, 2016 & 5800264 & 1047578 & $>100$ & School \\
\hline 7 & Sept. 15, 2016 & 58.09183 & 11.32073 & "enormous school" & School \\
\hline 8 & Sept. 16, 2016 & 58.09183 & 11.32073 & са. 100 & School \\
\hline 9 & Sept. 19, 2016 & 58.078 & 10.67 & 1 & Individuals \\
\hline 10 & Sept. 21, 2016 & 57.96167 & 10.50667 & 1 & Individuals \\
\hline 11 & Sept. 21, 2016 & 58.83729 & 11.03239 & a whole school & School \\
\hline 12 & Sept. 22, 2016 & 57.97375 & 10.79687 & Some fishermen saw 100s in & School \\
\hline
\end{tabular}




\begin{tabular}{|c|c|c|c|c|c|}
\hline & & & & $\begin{array}{l}\text { schools of different sizes. Other } \\
\text { fisherman "saw several jumping } \\
\text { tuna, lots of large splashes and } \\
\text { individual tunas under boat seen on } \\
\text { sonar" (Danish: "Så adskillige } \\
\text { springende tun, rigtig mange store } \\
\text { plask og enkelte fisk under båden } \\
\text { på loddet."). Others seen in } \\
\text { previous } 14 \text { days. }\end{array}$ & \\
\hline 13 & Sept. 24, 2016 & 57.97167 & 10.85833 & 1 & Individuals \\
\hline 14 & Sept. 30, 2016 & 57.469 & 10.539 & Small school (6-8 individual fish) & School \\
\hline 15 & Oct. 13, 2016 & 58.087 & 10.29167 & 1 & Individuals \\
\hline 16 & Oct. 17, 2016 & 57.033 & 11.7447 & ca. 5-10 & School \\
\hline 17 & Oct. 20, 2016 & 58.1 & 10.13333 & 1 & Individuals \\
\hline
\end{tabular}


625 Table S3. Examples of videos on social media of bluefin tuna Thunnus thynnus swimming and

626 jumping at surface in the Skagerrak-Kattegat and off Norway during 2015 and 2016. Also

627 indicated is the number of views of each videoclip. The total number of views was 270,291 as

628 of July 12, 2017.

\begin{tabular}{|c|c|c|c|c|c|}
\hline Link & Location & $\begin{array}{l}\text { Date recorded } \\
\text { or uploaded }\end{array}$ & Filmmaker & $\begin{array}{l}\text { Comments } \\
\text { and notes }\end{array}$ & $\begin{array}{l}\text { Views } \\
\text { as of } \\
\text { July } 12 \text {, } \\
2017\end{array}$ \\
\hline $\begin{array}{l}\text { https://www.youtube.com/watch?v } \\
=\text { =IKOF843Ew74 }\end{array}$ & Skagerrak & $\begin{array}{l}\text { Sept. 10, } 2015 \\
\text { (recorded) } \\
\text { Sept. 11, } 2015 \\
\text { (uploaded) }\end{array}$ & $\begin{array}{l}\text { Thomas } \\
\text { Kolmorgen; } \\
\text { Fiskeavisen } \\
\text {.dk }\end{array}$ & & 23,346 \\
\hline $\begin{array}{l}\text { https://www.youtube.com/watch?v } \\
=\text { Rd9mRhHTpt0 }\end{array}$ & $\begin{array}{l}\text { Swedish } \\
\text { west coast, } \\
\text { near } \\
\text { Måskeår }\end{array}$ & $\begin{array}{l}\text { Sept. } 15 \\
\text { (recorded), } \\
2016\end{array}$ & $\begin{array}{l}\text { Micael } \\
\text { Karlsson }\end{array}$ & & 40,961 \\
\hline $\begin{array}{l}\text { https://www.youtube.com/watch?v } \\
=\text { eXGZ4nUhk6w }\end{array}$ & $\begin{array}{l}\text { Ona, Møre, } \\
\text { Norway }\end{array}$ & $\begin{array}{l}\text { Sept. 16-17, } \\
2016 \\
\text { (recorded) } \\
\text { Oct. 11, } 2016 \\
\text { (uploaded) }\end{array}$ & $\begin{array}{l}\text { Magnus } \\
\text { Tangen }\end{array}$ & $\begin{array}{l}\text { Short } \\
\text { documenta } \\
\text { ry }(7: 22) \text { of } \\
\text { commercial } \\
\text { fishing on } \\
\text { Norwegian }\end{array}$ & 85,995 \\
\hline
\end{tabular}




\begin{tabular}{|c|c|c|c|c|c|}
\hline & & & & $\begin{array}{l}\text { vessel } \\
\text { Hillers } \varnothing y \text {, } \\
\text { which } \\
\text { captured } \\
190 \text { tunas } \\
\text { in one haul. }\end{array}$ & \\
\hline https://youtu.be/ESLOvS NZRk & Skagerrak & $\begin{array}{l}\text { Sept. 18, } 2016 \\
\text { (recorded) } \\
\text { Sept. 21, } 2016 \\
\text { (uploaded) }\end{array}$ & $\begin{array}{l}\text { Uffe } \\
\text { Nielsen }\end{array}$ & $\begin{array}{l}\text { Exact } \\
\text { location not } \\
\text { specified. } \\
\text { Can see } \\
\text { tuna in } \\
\text { distance. }\end{array}$ & 115,520 \\
\hline https://youtu.be/GSmDHQyDud8 & $\begin{array}{l}\text { West coast } \\
\text { of Sweden }\end{array}$ & $\begin{array}{l}\text { Uploaded } \\
\text { Sept. 17, } 2016\end{array}$ & $\begin{array}{l}\text { Bo } \\
\text { Svensson }\end{array}$ & $\begin{array}{l}\text { Very clear } \\
\text { and sharp } \\
\text { video; calm } \\
\text { water, easy } \\
\text { to see tuna }\end{array}$ & 4,469 \\
\hline
\end{tabular}


632 Author Contributions: BRM designed research, compiled data and wrote the manuscript; all

633 authors contributed to the design of the study and edited drafts of the manuscript. KA, MCh

634 assisted with data collection in Denmark and MCa assisted with data collection in Sweden. CS

635 and HSL assisted with data collection from recreational and commercial fishers. MRP produced

636 satellite imagery temperature products.

637

638

639

640 